\title{
PERANCANGAN BUKU PHOTO ESSAY TENTANG REKAM JEJAK PENINGGALAN TREM DI KOTA SURABAYA
}

\author{
Prayuda Djaya Kusuma ${ }^{1}$ \\ Muhammad Nasrulloh ${ }^{1}$ \\ Arjuna Bangsawan ${ }^{1}$ \\ Institut Informatika Indonesia, Surabaya ${ }^{l}$ \\ prayuda.desain@gmail.com
}

\begin{abstract}
Abstrak
Surabaya memiliki jalur trem pertama kali tahun 1886 berupa trem uap. Trem listrik di resmikan di Surabaya pada tahun 1923. Persaingan ketat dengan transportasi lain membuat trem mati pada tahun 1970. Namun peninggalan trem uap dan trem listrik masih dapat dijumpai, beberapa peninggalan seperti benda, bangunan, dan jalur sudah mulai hilang dan tidak terawat. Mengingat buku yang membahas tentang sejarah trem di perpustakaan dan instansi sangat sedikit. Ada beberapa buku yang membahas tentang trem seperti buku "Soerabaia Tempoe Doloe" dan buku "Mana Soerabaia Koe" namun belum membahas trem secara spesifik, banyak masyarakat kota Surabaya yang tidak mengetahui bahwa jaman dahulu di kota Surabaya ada transportasi trem uap dan trem listrik. Dalam konsep penelitian ini dipilih media buku foto esai untuk mengajak masyarakat mengetahui sejarah trem kota Surabaya, maka dibuatlah "Perancangan Buku Photo Essay Tentang Rekam Jejak Peninggalan Trem di Kota Surabaya". Media buku foto esai dipilih untuk memberikan kesan memorial dalam menyampaikan sebuah peristiwa dan tidak menggunakan foto tunggal (single photo). Melainkan terdiri dari rangkaian foto dan dikemas menjadi buku foto esai yang merekam jejak peninggalan trem di kota Surabaya.
\end{abstract}

Kata kunci: Sejarah, Photo Essay, Trem, Surabaya

\begin{abstract}
Surabaya has the first tramway in 1886 in the form of a steam tram. The electric tram was inaugurated in Surabaya in 1923. The fierce competition with other transportation made the tram die in 1970. But the remains of steam tram and electric tram can still be found, some relics such as objects, buildings, and lanes have started to disappear and are not maintained. Given the book that discusses the history of the tram in libraries and agencies is very little. There are several books on trams such as the book "Soerabaia Tempoe Doloe" and the book
\end{abstract}


"Mana Soerabaia Koe" but have not discussed the tram specifically, many people in Surabaya who do not know that the ancient city of Surabaya there is transportation steam tram and electric tram. In this research concept selected media essay photo book to invite people to know tram history of Surabaya city, hence made " Design Of Photo Book Essay About Tram Track Record In Surabaya City". Media photo book essay selected to give the impression of memorial in conveying an event and not using single photo. Rather it consists of a series of photographs and packed into a photo book of essays that record tram trail in the city of Surabaya.

Keywords: History, Photo Essay, Tram, Surabaya

\section{PENDAHULUAN}

Perkembangan sebuah kota merupakan hasil interaksi dari berbagai unsur pembentuk kota, seperti masyarakat serta berbagai kegiatan perekonomiannya. Begitu juga dengan lingkungan tempat tinggal masyarakatnya dan juga potensipotensi yang terdapat dalam sebuah kota tersebut, menjadi pendorong dalam berkembangnya suatu kota. Perkembangan jalan pada masa kolonial menjadi salah satu pengaruh penting dalam penggunaan mode transportasi yang disesuaikan dengan kondisi infrastruktur jalan raya pada masa tersebut.

Pada tahun 1869, trem merupakan kendaraan yang paling banyak dimanfaatkan oleh masyarakat Batavia. Belanda bergerak kearah timur menuju kota Surabaya yang dulu bernama Junggaluh, Ujunggaluh atau Hujunggaluh dibawah kepala kepemerintahan Adipati Jayengrono. Untuk memenuhi kebutuhan berdagang dan mengembangkan kota. Pada tahun 1886 Nederlands-Indische Spoorweg Maatschappij (NISM) membangun transportasi darat berupa trem uap, pada tahun 1889 trem uap mulai beroperasi dan dikelola trem oleh Ooster Java Stoomtram Maatschappij (OJS) sebagai anak perusahaan dari NISM.

Seiring perkembangan kota OJS memikirkan bagaimana transportasi di kota Surabaya semakin berkembang, pada tahun 1911 OJS membangun trem listrik yang membebaskan lahan cukup besar untuk membangun jalur dan pembangunan selesai pada tahun 1924. Trem mempunyai masa kejayaan pada tahun 1927 yang sekiranya 11,4 juta orang menggunakan trem listrik dan 5,2 juta menggunakan trem uap. Trem listrik mempunyai empat jalur, penyebutan jalur pada masa itu adalah lijn/lyn. Namun istilah lyn diwariskan pada transportasi angkutan umum dan 
jalur operasi beberapa angkutan umum di kota Surabaya sama persis dengan jalur operasi trem listrik. Transportasi di kota Surabaya pada zaman Hindia Belanda (1800-1942) sesungguhnya juga mengungkapkan perkembangan kota ini tatkala menapaki perubahan dari kota tradisional perlahan menjadi kota modern.

Harga tiket penumpang trem dibagi menjadi dua macam berdasarkan harga tiket kelas I untuk warga Belanda seharga 15 sen dan kelas II untuk pribumi seharga 10 sen. Ironisnya, kondisi itu justru menjadikan trem selalu merugi karena banyak penumpang yang tidak membayar. Buruknya manajemen Djawatan Kereta Api Republik Indonesia membuat keberadaan trem akhirnya "hidup segan mati tak mau". Persaingan ketat dengan transportasi lain yang lebih modern, akhirnya membuattrem di Surabaya mati pada tahun 1970 trem berhenti beroperasi pada tahun 1975 dan balaiyasa trem di Wonokromo Kota, Jl. Joyoboyo sudah tidak berfungsi pada tahun 1978 .

Untuk membuat masyarakat lebih tertarik membaca dan mencari tahu sejarah trem maka diperlukan perancangan media buku fotografi untuk lebih mengenal sejarah kota Surabaya. Media buku foto esai dipilih untuk memberi kesan memorial dalam menyampaikan peristiwa dan tidak menggunakan foto tunggal (single photo), Melainkan terdiri dari rangkaian foto dan dikemas menjadi buku foto esai yang merekam jejak sisa peninggalan trem uap dan trem listrik di kota Surabaya.

\section{KAJIAN TEORI}

\section{Teori Photo Story}

Photo story adalah pendekatan bercerita dengan menggunakan beberapa foto dan tambahan teks untuk menjelaskan konteks atau latar belakang. Fotografer ialah pencerita, fotografer harus mampu bertutur baik dan fokus sehingga rangkaian foto tetap terjaga arah dan artinya. Photo story memiliki kesan kuat, fokus, dan kreatif yang muncul dari satu foto cerita lebih kuat dibanding foto tunggal karena pembaca mengikuti cerita dari pembuka hingga penutup dan mendapatkan pengalaman yang mendalam. Kekuatan kesan tersebut muncul karena foto cerita lahir dari ide yang dipikir matang-matang dan difoto dengan persiapan yang baik. Fokus yang 
dimaksudkan bukanlah fokus dari optik lensa, melainkan ceritanya (Wijaya, 2016: $14)$.

Photo story dapat dikelompokkan dalam bentuk deskriptif yang sangat dokumenter, naratif, dan foto esai. Banyak orang menyamakan, atau menyebut, semua bentuk photo story sebagai foto esai. Namun sejatinya sajian photo story lebih beragam. Berikut penjelasan dari bentuk-bentuk photo story: a) Foto Deskriptif adalah foto yang menampilkan hal-hal menarik dari sudut pandang fotografer; b) Photo story naratif merupakan foto yang diikuti narasi yang bertutur menjelaskan dari satu kondisi atau keadaan hingga kondisi berikutnya; c) Foto esai selalu memperlihatkan cara pandang (point of view) fotografer terhadap suatu isu secara jelas

\section{Teori Layout}

Menurut Rustan, Surianto (2014:10), menjelaskan bahwa pada dasarnya layout dapat dijabarkan sebagai tataletak elemen-elemen desain terhadap suatu bidang. layout adalah suatu proses/ tahapan kerja dalam mendesain, namun definisi layout dalam perkembangannya sudah sangat meluas dan melebur dengan definisi desain itu sendiri Secara umum tujuan layout menyampaikan informasi dengan lengkap dan tepat. Memberi kenyamanan dalam membaca termasuk di dalamnya kemudahan mencari informasi yang dibutuhkan, navigasi, dan estetika. Elemen layout dibagi menjadi tiga yaitu elemen teks, elemen visual dan invisible element.

\section{Teori Cetak}

Menurut Damera, Anne (2002:10), hadirnya percetakan di Indonesia bermula dari kedatangan Belanda tiba tahun 1596 dan erat hubungannya dengan VOC. Perkembangan cetak di Indonesia dimulai dari tahun 1668 hingga tahun 2000. Proses pencetak bukanlah suatu yang mudah, melainkan suatu hal yang rumit dan sangat detail. Ada tiga fase besar didalamnya yaitu pra cetak (prepress), cetak (press), dan finishing (postpress). Pra cetak adalah bagian pertama, karena semua hasil cetakan bermula dari pra cetak. Mulai dari menentukan ukuran kertas, jenis lipatan, sampai jenis mesin yang digunakan. Pracetak dimulai dari input data sampai desain siap cetak atau Final Artwork. Fase cetak adalah proses pencetakan 
yang sebenarnya. Cetak merupakan reproduksi masal suatu produk, bisa puluhan, ratusan, ribuan, bahkan jutaan exemplar tergantung teknik cetak dan jenis mesinnya. Proses finishing adalah proses akhir untuk mempercantik hasil cetak suatu produk. Proses ini meliputi cutting, sortir, penjilidan, spot UV varnishing dan pengemasan

\section{METODE PENELITIAN}

Sebagai bentuk penelusuran terhadap permasalahan yang terjadi, maka dilakukan sejumlah penelitian. Penelitian yang dilakukan yaitu melalui: 1) Mengidentifikasi fenomena dan problematika; 2) Studi komparator dilakukan terhadap buku Soerabaia Tempoe Doloe dan buku Mana Soerabaia Koe 3) Hasil wawancara kepada sejarawan, istri masinis trem uap. Wawancara kepada masyarakat, pelajar, dan mahasiswa; 4) Studi literatur dan teori yang berhubungan dengan penelitian; 5) Hasil dari kuesioner untuk mengidentifikasi masalah

\section{HASIL DAN PEMBAHASAN}

\section{Konsep dan Proses Perancangan}

Konsep perancangan ini diperoleh dari keyword. Keyword diperoleh dari fenomena, inti masalah, positioning, dan target audiens. Sehingga diperoleh keyword yang sesuai yaitu history dan memorial. Dalam perancangan ini, sisi informatif diterapkan melalui konsep visual yang disertai oleh teks yang terkandung dalam media utama hingga media promosi.

Proses perancangan media utama yaitu buku foto esai yang diawali oleh pembuatan naskah cerita. Kemudian dilakukan pembuatan alur cerita foto sehingga dapat diketahui apa saja visual yang dibutuhkan. Tahapan dari proses desain adalah sketsa alternatif, digital alternatif, desain terpilih, hingga desain final. Berikut adalah proses desain yang dilakukan: 


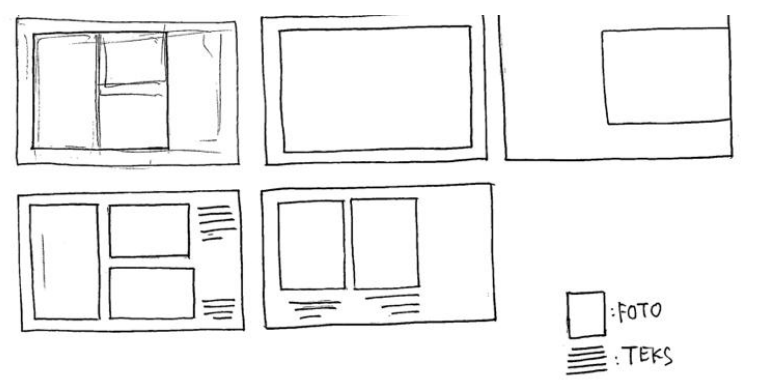

Gambar 1. Proses Sketsa Layout

Sumber: Dokumentasi Pribadi

Gambar sketsa layout buku dapat memudahkan proses desain digital. Setelah melalui proses sketsa dan penyederhanaan desain, maka desain sampul menggunakan gaya futurisme dan desain layout menggunakan gaya white space. Tipografi menggunakan jenis huruf cursive.

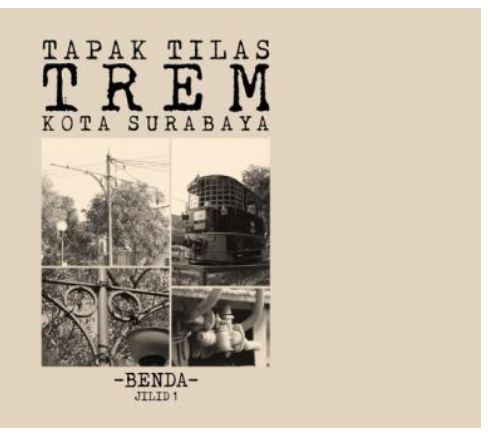

Gambar 2. Desain Digital Sampul Buku Bagian Depan Benda Jilid 1

Sumber: Dokumentasi Pribadi

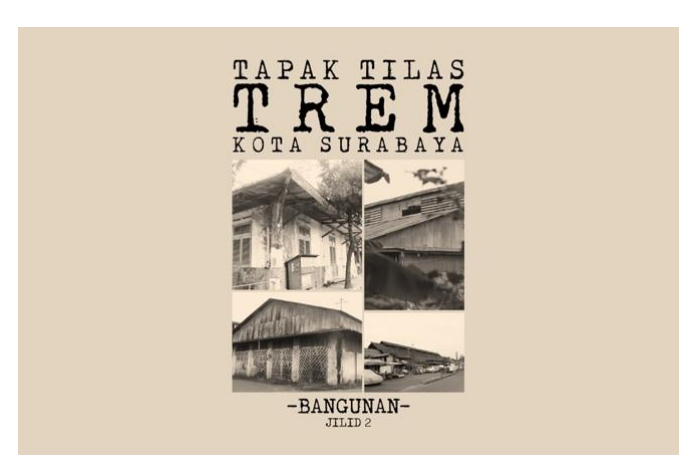

Gambar 3. Desain Digital Sampul Buku Bagian Depan Bangunan Jilid 2

Sumber: Dokumentasi Pribadi 


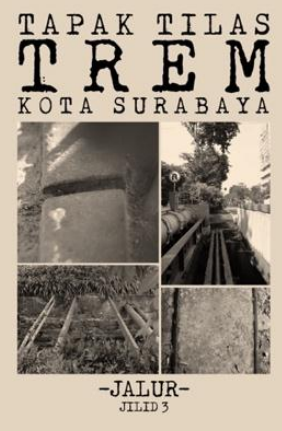

Gambar 4. Desain Digital Sampul Buku Bagian Depan Jalur Jilid 3

Sumber: Dokumentasi Pribadi

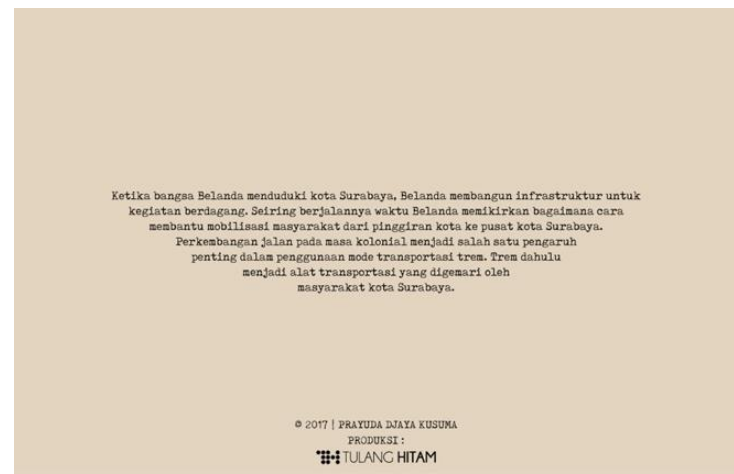

Gambar 5. Desain Digital Sampul Buku Bagian Belakang

Sumber: Dokumentasi Pribadi

\section{JILID 1 TAPAK TILAS TREM KOTA SURABAYA $\because \because:$ TULANC HITAM \\ Gambar 6. Desain Digital Punggung Buku \\ Sumber: Dokumentasi Pribadi}

Setelah melalui proses sketsa desain layout buku, maka jadilah desain layout buku menggunakan gaya white space dan tipografi menggunakan jenis huruf cursive sebagai berikut: 


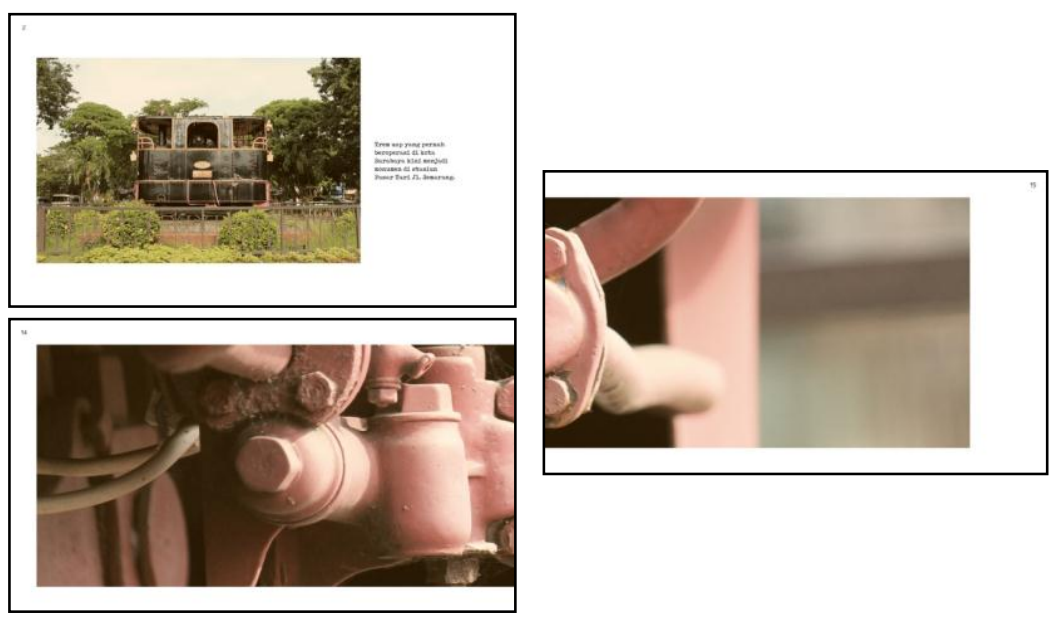

Gambar 7. Layout Digital Buku Benda Jilid 1

Sumber: Dokumentasi Pribadi
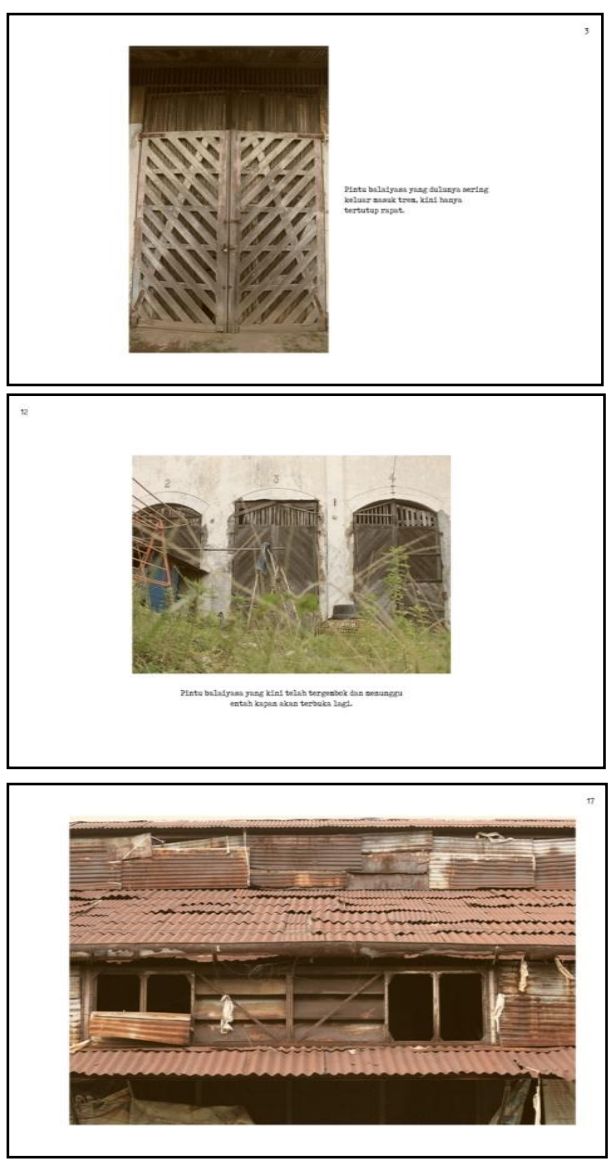

Gambar 8. Layout Digital Buku Bangunan Jilid 2

Sumber: Dokumentasi Pribadi 

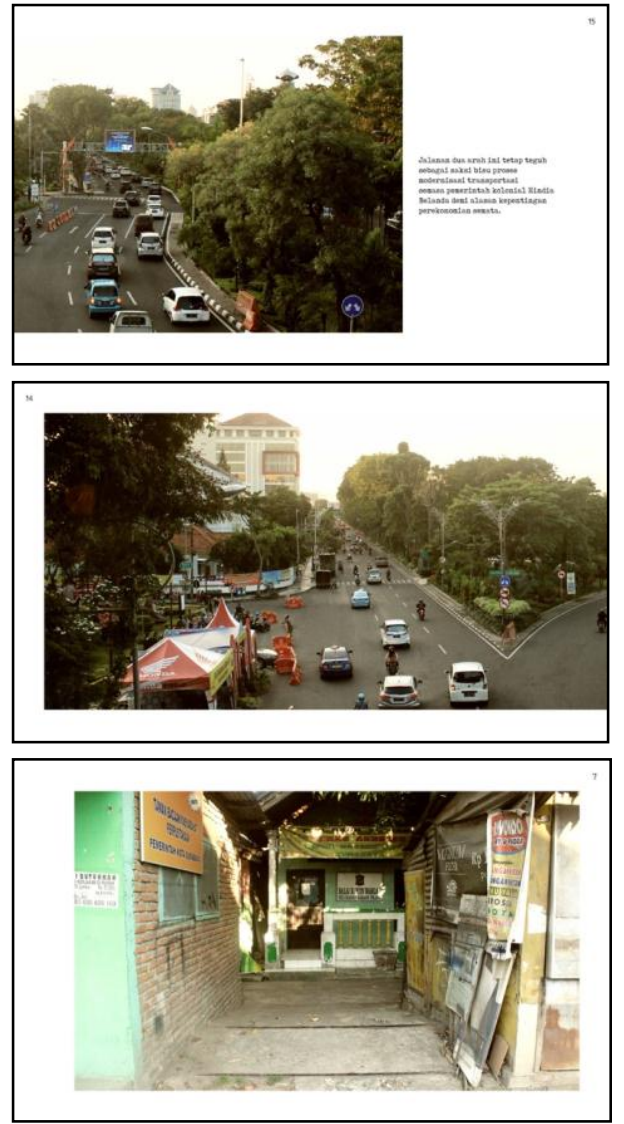

\section{Gambar 9. Layout Digital Buku Bangunan Jilid 2}

Sumber: Dokumentasi Pribadi

\section{SIMPULAN DAN SARAN}

\section{Simpulan}

Pembangunan transportasi trem oleh bangsa Belanda untuk memenuhi kebutuhan berdagang dan mengembangkan kota. Pada tahun 1886 NederlandsIndische Spoorweg Maatschappij (NISM) membangun trem uap, setelah itu pada tahun 1911 membangun trem listrik dan dikelola oleh Ooster Java Stoomtram Maatschappij (OJS) sebagai anak perusahaan dari NISM. Trem mempunyai masa kejayaan pada tahun 1927 yang sekiranya 11,4 juta orang menggunakan trem listrik dan 5,2 juta menggunakan trem uap. Persaingan ketat dengan transportasi lain membuat trem mati pada tahun 1970 dan trem berhenti beroperasi pada tahun 1975. Namun peninggalan trem uap dan trem listrik masih 
dapat dijumpai, beberapa peningglan seperti benda, bangunan, dan jalur sudah mulai hilang dan tidak terawat.

Wacana Pemerintah Kota Surabaya membangun trem kembali dan mengaktifkan jalur trem yang dulu untuk mengatasi sebuah kemacetan yang sering terjadi di kota Surabaya. Namun nama armadanya yang akan dibangun oleh Pemerintah Kota Surabaya bukan lagi trem uap dan trem listrik, melainkan Suro Tram dan Boyo Rail. Buku foto esai "Tapak Tilas Trem Kota Surabaya" ini mampu menjadi sebuah media yang menggambarkan keberadaan trem jaman dahulu yang menjadi moda transportasi masyarakat kota Surabaya

\section{Saran}

Untuk menyempurnakan hasil penelitian terhadap "Tapak Tilas Trem Kota Surabaya" ini terdapat beberapa saran yang dapat digunakan dalam penelitian kedepan. Beberapa diantaranya adalah narasumber, penulisan caption, serta urutan dalam pemilihan foto. Agar analisa tentang trem yang disertakan lebih akurat dan informatif, diperlukan penambahan narasumber yang kompeten dalam bidangnya sebagai bahan pertimbangan penelitian. Selain itu, penulisan caption yang repetitif dan hanya menekankan pada objek foto harus disempurnakan dengan cara menguraikan secara lebih detail segala aspek yang terdapat dalam karya foto tersebut. Untuk menambahkan kesan memorial dalam menyampaikan peristiwa diperlukan pemilihan foto yang runut sesuai dengan alur cerita.

\section{DAFTAR PUSTAKA}

Dameria, Anne. 2008. Basic Printing. Jakarta: Link \& Match Graphic.

Rustan, Surianto. 2014. Layout Dasar dan Penerapannya. Jakarta: PT. Gramedia Utama Pustaka.

Wijaya, Taufan. 2016. Photo Story Handbook. Jakarta: PT Gramedia Pustaka Utama 